\title{
IDENTIDADES PROBLEMÁTICAS: CONFIGURAÇÕES DO HOMOEROTISMO MASCULINO EM NARRATIVAS PORTUGUESAS E BRASILEIRAS (1881-1959)
}

José Carlos Barcellos Universidade do Minho

"E aquela era a hora do mais tarde. O céu vem abaixando. Narrei ao senhor. No que narrei, o senhor talvez até ache mais do que eu, a minha verdade."

Guimarães Rosa

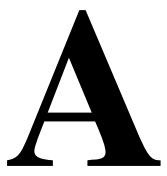

hora do mais tarde... O objetivo deste texto é investigar, ao longo de quase oito décadas, algumas das estratégias através das quais narrativas portuguesas e brasileiras procuraram conhecer, reconhecer e dizer o amor entre homens, antes que a revolução sexual dos anos 60 viesse modificar radicalmente práticas e linguagens, abrindo caminho para a(s) identidade(s) gay (s) contemporânea(s). Aceitando, com Jurandir Freire Costa, que "vocabulários diversos criam ou reproduzem subjetividades diversas. E, conforme a descrição de nossas subjetividades, interpretamos a subjetividade do outro como idêntica, familiar ou como estranha, exótica e até mesmo desumana" configurações discursivas segundo as quais os perfis e os sentidos do homoerotis-mo masculino vieram sendo pensados e problematizados no espaço ficcional de língua portuguesa, desde o final do séc. XIX

${ }^{1}$ COSTA, 1992, p. 14. 
até o limiar dos anos 60.

Como ponto de partida, cabe explicitar alguns pressupostos teóricos que fundamentam a metodologia adotada. Rejeitamos liminarmente qualquer visão de uma suposta identidade homos-sexual essencialista e pré-determinada, de caráter trans-histórico e transcultural. Eis por que não falamos de representação do homoerotismo na literatura, mas sim de configurações literárias do mesmo. Ou seja, postulamos que é na linguagem e através dela que as experiências se fazem enquanto tais no momento mesmo em que se dizem. É, pois, no espaço histórico e social da(s) linguagem(ns), que procuraremos detectar as diferentes experiências homoeróticas que chegaram a se configurar nas narrativas estudadas. Como escreve Dennis Allen,

J'estime que l'examen de la relation entre homosexualité et écriture ne doit pas porter sur les modalités d'encodage et d'in-corporation d'une homosexualité pré-existante. Il faudra au contraire vérifier comment le texte définit et décrit (et donc "crée") l'homosexualité dont il parle. ${ }^{2}$

Procuramos também empregar o termo homoerotismo, de preferência a homossexualismo, por várias razões: em primeiro lugar, por não estar marcado pelo contexto médico-legal e psiquiátrico que forjou a noção de "homossexual" na segunda metade do séc. XIX; além disso, pelo fato de "eros" ser um conceito muito mais abrangente que "sexo", o que permite integrar ao objeto de estudo uma gama muito mais variada, matizada e rica de emoções, sensações, idéias e vivências; em terceiro lugar, para passar ao largo da problemática noção de orientação sexual, em seus vários desdobramentos e, sobretudo, em contraste com a noção de opção sexual; e, finalmente, para evitar a falaciosa transformação de um adjetivo (homossexual) em substantivo ( o homossexual), como se práticas sexuais pudessem definir, caracterizar e nomear aprioristica-mente um tipo de pessoa, independentemente do meio social e do momento histórico em que ela vive e atua, bem como das inúmeras variáveis psicológicas, culturais,

2 ALLEN, 1994, p. 20. 
étnicas, políticas, religiosas etc. que plasmam a sua existência e sua autocompreensão. ${ }^{3}$

Essa opção não quer dizer que estejamos ignorando ou minimizando a complexa questão das identidades e das subculturas, no contexto atual dos estudos culturais. ${ }^{4}$ Pelo contrário. Simplesmente, sustentamos que o homoerotismo não leva necessariamente à constituição de uma identidade ou de uma subcultura específica. Como bem assinala Jeffrey Weeks,

Much recent work has stressed the vital importance of distinguishing among behavior, role, and identity in any sociological or historical approach to the subject of homosexuality. Cross-cultural studies, as well as studies of schoolboy sex play, prison homosexuality, and sex in public places, show that homosexual behavior does not give rise automatically, or even necessarily, to a homosexual identity. Homosexual roles and identities are historically constructed. ${ }^{5}$

Essas considerações abrem duas perspectivas extremamente importantes para o nosso estudo. A primeira delas nos levaria a sublinhar o caráter histórico e contingente da própria noção de identidade e do papel que esta desempenha na cultura ocidental. Num ensaio brilhante, o professor inglês Jonathan Dollimore, comparando André Gide a Oscar Wilde - e valorizando decidida-mente a envergadura crítica do pensamento aparentemente frívolo do segundo desses autores -, aponta para o papel central que a idéia de um "eu autêntico" desempenha na cultura moderna do Ocidente. No espaço

${ }^{3}$ Sobre essa questão, um bom ponto de partida é o texto de John Boswell, "Hacia un enfoque amplio. Revoluciones, universales y categorías relativas a la sexualidad." (BOSWELL, 1985, p.38-74). Apesar de um pouco antigo, não perdeu sua atualidade e relevância.

${ }^{4}$ Sobre a existência de uma cultura gay, cf. PIETRANTONI, 1998, p.12-13; MAGGI, 1998, p.14-16; e ainda a revista Stylistica nº 4, 1995-96 (Monográfico sobre Cultura Homosexual).

5 WEEKS, 1990, p. 196. 
cultural da modernidade, marcado pelo processo de secularização, esse suposto "eu autêntico" passa a ocupar o antigo lugar de Deus, convertendo-se na instância decisiva para a fundamentação do verdadeiro, do real (e/ou natural) e do moral, "categories which correspond to the three main domains of knowledge in Western culture: the epistemological, the ontological, and the ethical". ${ }^{6} \mathrm{O}$ fato de os diferentes movimentos libertários (feminista, negro ou gay, p. ex.), num primeiro momento, terem recorrido precisamente a essa noção de autenticidade, para fundamentar suas próprias reivindicações e lutas nos campos social, político e cultural, ${ }^{7}$ não nos deve levar a nenhuma forma de sacralização essencialista e a-histórica da própria noção de identidade e do seu valor cultural e político. ${ }^{8}$

Assim, chegamos à segunda perspectiva de que falávamos acima. Num estudo como o nosso, não podemos nem devemos aplicar retrospectivamente as identidades gay (entendida aqui como a daqueles homens que se definem primariamente em função de um estilo de vida multidimensional, estruturado a partir de uma opção afetiva e/ou sexual homoerótica) e queer (marcada ainda, além disso, por uma opção cultural e política radical "centrada sobre a re-significação dos valores e significações da cultura dominante", consoante as palavras de Dennis Allen) às experiências homoeró-ticas configuradas nos textos que estaremos analisando. ${ }^{9}$ O que nos cabe é procurar entender outras

${ }^{6}$ DOLLIMORE, 1996, p. 39.

${ }^{7}$ Como expressão paradigmática dessa postura, leiam-se as seguintes palavras de Mario Mieli: "La dura persecuzione dell'omosessualità ha indotto noi gay a vincolarci strettamente alla nostra identità di omosessuali: per difenderci, per affermarci, dovevamo anzitutto saper resistere, saper essere omosessuali. Per questo il movimento gay ha particolarmente enfatizzato la tematica dell' identità omosessuale". (MIELI, 1977, p. 189)

${ }^{8}$ A obra de Frédéric Martel, Le rose et le noir (MARTEL, 1996) é imprescindível para o debate político contemporâneo, em que ao "direito à diferença", pedra de toque do multiculturalismo norte-americano, contrapõe-se a reivindicação de um "direito à indiferença", cujo fundamento é a idéia de cidadão, conforme a tradição republicana francesa. 
formas históricas - e, no nosso caso, literárias - de apreensão e compreensão dessas experiências, em suas especificidades e contexturas próprias. Como escreve George Chauncey Jr.,

(...) we need to begin paying more attention to other social forms of homosexuality - other ways in which homosexual relations have been organized and understood, differentiated, named, and left deliberately unnamed. We need to specify the particularity of various modes of homosexual behavior and the relationships between those modes and particular configurations of sexual identity. ${ }^{10}$

Isso posto, vamos aos textos.

\section{Entre o inefável e o nefando}

Em 1906, Machado de Assis publica o volume de contos Relíquias de Casa Velha, ao qual antepôs o belíssimo canto do amor conjugal que é o soneto "A Carolina". Um dos contos do volume, intitulado "Pílades e Orestes", apresenta um enredo curioso: dois amigos, Quintanilha e Gonçalves, que poderíamos descrever como de classe média acomodada, nutrem um profundo e sólido afeto um pelo outro, numa verdadeira comunhão de vida, até que o primeiro deles se enamora de uma parenta, Camila; depois de muita hesitação, Quintanilha conta ao amigo seu interesse pela moça e, diante da enigmática e fria reação de Gonçalves, conclui que este também deveria amá-la; então, numa decisão súbita, Quintanilha simplesmente desiste do casamento planejado em prol do companheiro, que vem efetivamente a desposar Camila.

A união de Quintanilha e Gonçalves é descrita em termos fortes:

${ }^{9}$ Uma obra relativamente recente que, a nosso ver, incorre gravemente nesse erro é o livro de Christopher Robinson, Scandal in the Ink (ROBINSON, 1995)

${ }^{10}$ CHAUNCEY Jr., 1990, p. 315. 
A vida que viviam os dois, era a mais unida deste mundo. Quintanilha acordava, pensava no outro, almoçava e ia ter com ele. Jantavam juntos, faziam alguma visita, passeavam ou acabavam a noite no teatro.

A união dos dois era tal, que uma senhora chamava-lhes os "casadinhos de fresco", e um letrado, P1lades e Orestes. ${ }^{11}$

No entanto, essa relação tem um quê de melancolia e sofrimento, não sendo totalmente simétrica:

Eles riam, naturalmente, mas o riso de Quintanilha trazia alguma coisa parecida com lágrimas: era, nos olhos, uma ternura úmida. Outra diferença é que o sentimento de Quintanilha tinha uma nota de entusiasmo, que absolutamente faltava ao de Gonçalves; mas, entusiasmo não se inventa. É claro que o segundo era mais capaz de inspirá-lo ao primeiro do que este a ele. ${ }^{12}$

Por isso, diz-nos o narrador que Quintanilha não era inteiramente feliz e também que "uma pancadinha no ombro ou no ventre, com o fim de aprová-lo ou só acentuar a intimidade, era para derretê-lo de prazer. Contava o gesto e as circunstâncias durante dois e três dias". ${ }^{13}$

Dois aspectos chamam imediatamente nossa atenção em "Pílades e Orestes": em primeiro lugar, o caráter inefável da relação entre Quintanilha e Gonçalves, não apenas no discurso que o narrador dirige ao leitor, mas sobretudo no discurso dos próprios personagens. O momento mais eloqüente desse silêncio, que percorre todo o conto, é aquele em que Quintanilha expõe a Gonçalves seus planos de casamento com Camila:

- Você aprova, Gonçalves?

Gonçalves empalideceu, - ou, pelo menos, ficou sério; nele a seriedade confundia-se com a palidez. Mas, não; verdadeiramente ficou

\footnotetext{
${ }^{11}$ MACHADO DE ASSIS, 1952, p. 125 e 128.

${ }^{12}$ MACHADO DE ASSIS, 1952, p. 128.

${ }^{13}$ MACHADO DE ASSIS, 1952, p. 129.
} 
pálido.

- Aprova? repetiu Quintanilha.

Após alguns segundos, Gonçalves ia abrir a boca para responder mas fechou-a de novo, e fitou os olhos "em ontem", como ele mesmo dizia de si, quando os estendia ao longe. ${ }^{14}$

No emudecimento de Gonçalves e na incompreensão do próprio Quintanilha, temos o silenciamento não apenas de uma fala, mas da própria experiência do mútuo afeto que ambos viviam e que não tinha outra linguagem para se pensar e expressar senão a da amizade. $O$ narrador, por sua vez, dispõe de alguns recursos expressivos a mais que seus personagens, mas tampouco consegue nomear diretamente a singularidade da amizade de Quintanilha e Gonçalves. Desses recursos, dois são particularmente significativos: a alusão à cultura greco-romana e a comparação com o amor paterno. As duas estratégias - e sobretudo a primeira - desempenha-ram historicamente um importante papel nos esforços para se pensar e dizer com dignidade o homoerotismo.

No final do séc. XIX/início do séc. XX, os elementos homoeróticos das culturas antigas são tomados como verdadeiros modelos a partir dos quais se procura plasmar uma nova linguagem que rompa o silenciamento da própria experiência, como vemos, com elegante ironia, nesse conto. Na ausência de outro referencial cultural, volta-se ao passado, em busca de formas para se pensar o presente e eventualmente planejar o futuro... A alusão ao amor paterno, por sua vez, é outro recurso, empregado com muita sutileza pelo narrador machadiano, nesse mesmo sentido de procurar dizer o indizivel. Tendo o cuidado de observar que os personagens "eram quase da mesma idade", assim justifica o narrador tão inesperada comparação: "A idéia da paternidade nascia das maneiras com que o primeiro tratava o segundo; um pai não se desfaria mais em carinhos, cautelas e pensamentos." 15

Não obstante esses esforços por encontrar uma linguagem apta

${ }^{14}$ MACHADO DE ASSIS, 1952, p. 133. 
a enunciar a especificidade do afeto de Quintanilha e Gonçalves, mantém-se, até o final do conto, o silenciamento da experiência dos dois amigos. Morto Quintanilha, o narrador pode tentar ainda, numa última ironia, tornar eloqüente o próprio silêncio: "Orestes vive ainda, sem os remorsos do modelo grego. Pílades é agora o personagem mudo de Sófocles. Orai por ele!”. ${ }^{16}$ Cabe mencionar de passagem que esse silenciamento é de tal ordem, que ainda em 1959 um crítico do porte de Astrojildo Pereira pôde analisar longamente o texto machadiano em apreço, sem se dar conta do caráter homoerótico da relação dos dois personagens, que ele descreve como "dois amigos como se fossem dois irmãos”, comparação esta que absolutamente não aparece no conto do escritor fluminense e altera-lhe profundamente o alcance. ${ }^{17}$

O segundo aspecto digno de nota a esse respeito, em Machado de Assis, e que se vincula estreitamente ao processo de silenciamento que acabamos de apontar, é o meio social em que se passa a história, uma classe média urbana com instrução superior e pacatos e comedidos hábitos burgueses. Pelo menos no âmbito das literaturas de língua portuguesa do final do séc. XIX/início do séc. XX, trata-se, nesse particular, de uma exceção. Em geral, o homoerotismo aparece configurado como índice de extremo refinamento ou revoltante aviltamento do personagem, mas não como uma possibilidade de vida, entre outras, para pessoas comuns provenien-tes dos estratos médios da sociedade. Daí a ausência de uma lingua-gem socialmente aceita, que fosse apta a dar conta dos sentimentos de Quintanilha e Gonçalves. Na verdade, são as estéticas decaden-tistas e naturalistas as que primeiro conseguirão dizer literariamente o homoerotismo no arco temporal que estamos considerando. As configurações que lhe dão estão inequivocamente marcadas pelos seus respectivos códigos, como requinte ou abjeção, nos termos acima apontados e que

\footnotetext{
${ }^{15}$ MACHADO DE ASSIS, 1952, p. 123.

${ }^{16}$ MACHADO DE ASSIS, 1952, p. 138.

${ }^{17}$ PEREIRA, 1959, p. 211.
} 
exemplificaremos a seguir. Nesse sentido, sublinhem-se o pioneirismo e a independência literária de Machado de Assis, em sua maneira de perspectivar o homoerotismo fundamentalmente como essa relação afetiva $^{18}$ não nomeável que, no entanto, habita o espaço trivial da existência cotidiana de pessoas comuns.

Em contraposição direta ao que estamos observando em "Pílades e Orestes”, poderíamos mencionar o romance Bom-Crioulo (1895), de Adolfo Caminha. ${ }^{19}$ Nele, o homoerotismo aparece num contexto bem específico, em que as relações de hierarquia e poder de uma sociedade escravocrata assumem um caráter nitidamente sadomasoquista. O romance flagra esse processo no ambiente da marinha, através do envolvimento afetivo e sexual de Amaro, o BomCrioulo, um ex-escravo "muito alto e corpulento (...) com um formidável sistema de músculos", com Aleixo, grumete de quinze anos, "o belo marinheirito de olhos azuis (...) com um arzinho ingênuo de menino obediente". ${ }^{20}$ Bom-Crioulo envolve, corteja, defende e educa Aleixo em sua nova vida, espicaçado pelo desejo de possuí-lo, desde a primeira vez que o vira. Consumado, ainda no navio, o "delito contra a natureza", Amaro vai tomando nova consciência de si, à medida que o relacionamento com Aleixo vai se estabilizando, num quarto alugado de um bairro pobre do Rio de Janeiro:

(...) Bom-Crioulo sentia uma febre extraordinária de erotismo, um delírio invencível de gozo pederasta... Agora compreendia nitidamente que só no homem, no próprio homem, ele podia encontrar aquilo que debalde procurava nas mulheres. Nunca se apercebera de semelhante anomalia, nunca em sua vida tivera a lembrança de perscrutar suas tendências em

${ }^{18}$ A esse respeito, observe-se o contraste marcante entre a perspectiva machadiana e a do célebre relatório do chefe de polícia de Paris, François Carlier, publicado em 1887, segundo o qual a "pederastia" estava necessariamente ligada à prostituição. Cf. FERNANDEZ, 1992, p.38.

${ }^{19}$ Sobre o homoerotismo em Bom-Crioulo, cf. ANTELO, 1997, p.9-21, CRUZ, 1997, p. 47-67.

${ }^{20}$ CAMINHA, 1983, p. 15 e 21. 
matéria de sexualidade. As mulheres o desarmavam para os combates do amor, é certo, mas também não concebia, por forma alguma, esse comércio grosseiro entre indivíduos do mesmo sexo; entretanto, quem diria!, o fato passava-se agora consigo próprio, sem premeditação, inesperadamente. E o mais interessante é que "aquilo" ameaçava ir longe, para mal de seus pecados... Não havia jeito, senão ter paciência, uma vez que a "natureza" impunha-lhe esse castigo. (...) Se os brancos faziam, quanto mais os negros! É que nem todos têm força para resistir: a natureza pode mais que a vontade humana... ${ }^{21}$

Esse trecho é extremamente interessante enquanto perspectivação naturalista do desejo homoerótico no contexto de uma sociedade marcada pelo racismo. Trata-se de um instinto natural mas que, ao mesmo tempo, é um castigo, um opróbrio, um ato grosseiro, baixo, ao qual, no entanto, não escapam sequer os supostamente "superiores" brancos. De qualquer forma, é algo vil e aviltante. Nesse particular, parece ser menos grave o ato em si, que o seu desdobramento numa relação afetiva e social: “aquilo’ ameaçava ir longe”. No que diz respeito aos papéis sexuais, há uma clara definição dos mesmos: trata-se de uma relação pederástica - eco tardio de uma pretensa Antigüidade greco-romana - nitidamente caracterizada a partir da própria descrição física dos personagens. Bom-Crioulo é inequivocamente um homem "viril"; para ele, o que está em jogo é simplesmente o objeto de satisfação do seu desejo, que se desloca da mulher para o adolescente, e não sua auto-identificação.

Convém ainda atentar para a ambigüidade do conceito de natureza no texto de Caminha: o homoerotismo é simultaneamente "contra a natureza" e imposto por ela. No primeiro caso, temos o discurso filosófico, jurídico e até teológico da tradição; no segundo, o discurso científico, moderno para a época. Entre ambos, o naturalismo de Caminha não consegue resolver os próprios problemas éticos que levanta. "Não havia jeito, senão ter paciência"...

Do ponto de vista da construção da narrativa, o "problema" ou

${ }^{21}$ CAMINHA, 1983, p. 32. 
nó dramático do romance surgirá quando Aleixo, seduzido pela senhoria, sentir a sua própria virilidade despertada e, em conseqüência, afastarse de Bom-Crioulo e do papel passivo que lhe cabia na relação com o negro. Portanto, a própria estruturação do romance depende de uma particular configuração do homoerotismo enquanto pederastia, conforme apontamos acima. Semelhante configuração, como vimos, dá conta da idéia naturalista de instinto, compatibilizando-a com a identidade masculina tradicional. Nesse sentido, o homoerotismo não seria tanto um problema para o sujeito quanto para o objeto do desejo pederástico. Por outras palavras, não se vê uma identidade pederástica autônoma em relação ao modelo de identidade masculina convencional. Para o pederasta, o problema estaria apenas na continuidade da relação, frente a uma (previsível) futura insubmissão do jovem amado, no momento em que este também quisesse assumir a identidade masculina.

Já o romance O Barão de Lavos (1891), do escritor português Abel Botelho, apresenta não somente muitos pontos de contacto com BomCrioulo, impregnados que estão ambos os textos dos códigos naturalistas então vigentes, como também algumas diferenças notáveis. Trata-se, uma vez mais, de uma relação pederástica: nesse caso, entre um aristocrata casado, o barão, e Eugênio, um jovem prostituto, para quem o amante monta casa. A diferença étnica entre Amaro e Aleixo é substituída pela de classe social, como se vê.

Observa-se n' O Barão de Lavos a mesma inconsistência entre a afirmação do instinto como força irresistível da natureza, contra a qual a consciência moral do barão tenta infrutiferamente lutar, e a condenação ética do comportamento ditado pelo mesmo instinto, que se apregoa inexorável. O texto justapõe expressões como "instintos pederastas", "vício secreto", "alma latrinária", "turbulências fatais de sodomita", "bulimia sensual" e inúmeras outras desse jaez e de similares efeitos retóricos, com a finalidade de mostrar-nos o mundo interior do protagonista. Ao contrário de Bom-Crioulo, porém, O Barão de Lavos explora amplamente a idéia da degenera-ção moral do personagem central como sintoma da degenerescência física de sua família. Nesse sentido, procura-se resolver a inconsistência da condenação ética acima 
apontada, num sistema fechado, absolutamente sem saída, em que o moral é um subprodu-to do físico.

Curiosamente, o romance também se volta com freqüência para elementos da cultura clássica e renascentista, numa espécie de arqueologia do "vício" do barão. O efeito resulta interessante, na medida em que se pode perceber como que um embrião de um discurso nobilitante do homoerotismo, disseminado pelo discurso dominante e avassalador da degeneração física e moral. Desses elementos clássicos, o mais importante e significativo é um quadro que representa Ganimedes $^{22}$, obra pela qual o barão tem grande apreço e que o acompanha até os últimos graus da sua decadência humana e social, como um último fio de dignidade de sua (auto) imagem, em acelerado processo de decomposição.

Em relação à pederastia propriamente dita, o romance de Abel Botelho também segue um caminho inverso ao daquele seguido pela obra de Adolfo Caminha. No contexto da idéia de degeneração, o barão paulatinamente vai passar do papel ativo para o passivo, o que é visto como mais um índice de sua decadência física e moral:

A plenitude de vida, a arrogância genital, a evolução orgânica ao máximo, próprias dos 32 anos, mantinham no barão ainda fortes e dominantes as tendências naturais da virilidade. Ele tinha por enquanto junto do efebo os mesmos apetites de penetração e de posse que o homem sente de ordinário para com a mulher. Todavia, em raros momentos de vertigem, ao contacto da sua carne com aqueloutra virilidade impetuosa e fresca, percorria-lhe os músculos, fugidio, breve, um movimento efeminado; faiscava-lhe no espírito uma pregustação de prazer que tivesse por base a passividade, o abandono; entrava de supurar-lhe da vontade uma solicitação em escorço de se entregar, de ser possuído, gozado, de ser femeado em suma. O que era, a um tempo, corolário do seu

${ }^{22}$ Acerca da importância do mito de Ganimedes como forma de se pensar e dizer e homoerotismo no Renascimento, cf. SASLOW, 1989. 
temperamento, e sinal patognómico do finalizar duma raça inútil, do agonizar duma família que vinha assim desfazer-se, podre das últimas aberrações e das últimas baixezas, na pessoa do seu representante derradeiro. ${ }^{23}$

Nesse sentido, pode-se falar de uma identidadeautônoma - ainda que extremamente negativa - do pederasta/sodomita em O Barão de Lavos, ao passo que em Bom-Crioulo, como vimos, se está muito próximo do modelo convencional de identidade masculina, que não chega a ser propriamente questionado. No romance brasileiro, o desejo homoerótico volta-se todo para o objeto; no romance português, ele reflui sobre o sujeito, desintegrando-o. Nessa perspectiva, há claramente em O Barão de Lavos uma condição bomoerótica, de caráter acentuadamente trágico, que não se observa em Bom-Crioulo.

No entanto, assim como no romance de Adolfo Caminha observamos a presença simultânea de conceitos de natureza não somente diferentes, mas até antagônicos, no de Abel Botelho o mesmo se dá em relação às idéias de condição trágica, vício ou degenerescência física e moral. Nessa caracterização polifacética do personagem, com acentuado predomínio da idéia de degeneração, podemos perceber a concorrência dos diferentes discursos que na época procuravam dar conta do homoerotismo. ${ }^{24}$ Como escreve María Ángeles Toda Iglesia,

Para evitar que el recién definido "problema homosexual" se interprete a la luz de las teorías de moda sobre la degeneración física y moral, los teóricos defensores de la homosexualidad (como André Raffalovich o J. A. Symonds) intentan matizar cautelosamente el concepto hasta definir la homosexualidad como una condición innata, inevitable, pero no degenerativa o patológica, y no como un vicio voluntario. No obstante, la idea de "condición" no sólo conlleva la de identidad, sino que la carga de un matiz de "sino trágico" que será uno de sus rasgos más obsesivos. ${ }^{25}$

Cabe ressaltar, porém, que, em termos de desdobramento do enredo, o aspecto fundamental da decadência do barão é de ordem econômica. Como conseqüência de sua obsessão erótica, ele descura a administração de seu patrimônio e acaba na miséria, e é esta que

${ }^{23}$ BOTELHO, 1982, p. 92. 
propriamente destrói seu casamento e sua ligação com Eugênio. Na ótica do romance - e sobretudo na da sociedade burguesa, cujo discurso médico e jurídico criou a figura do "homossexual" -, a decadência do barão é total...

Ainda no quadro do naturalismo, O Cortiço (1890), de Aluísio Azevedo, apresenta, através de um personagem completamente secundário dentro do enredo, uma configuração do homoerotismo distinta das até aqui consideradas. Referimo-nos ao Albino, morador do cortiço que o narrador apresenta nos seguintes termos:

Fechava a fila das primeiras lavadeiras, o Albino, um sujeito afeminado, fraco, cor de espargo cozido e com um cabelinho castanho, deslavado e pobre, que lhe caía, numa só linha, até ao pescocinho mole e fino. Era lavadeiro e vivia sempre entre as mulheres, com quem já estava tão familiarizado que elas o tratavam como a uma pessoa do mesmo sexo; em presença dele falavam de coisas que não exporiam em presença de outro homem; faziam-no até confidente dos seus amores e das suas infidelidades, com uma franqueza que não revoltava, nem comovia. Quando um casal brigava ou duas amigas se disputavam, era sempre Albino quem tratava de reconciliá-los, exortando as mulheres à concórdia. Dantes encarregavase de cobrar o rol das colegas, por amabilidade; mas uma vez, indo a uma república de estudantes, deram-lhe lá, ninguém sabia por que, uma dúzia de bolos, e o pobre-diabo jurou então, entre lágrimas e soluços, que nunca mais se incumbiria de receber os róis.

E daí em diante, com efeito, não arredava os pezinhos do cortiço, a não ser nos dias de carnaval, em que ia, vestido de dançarina, a passear à tarde pelas ruas e à noite dançar nos bailes dos teatros. Tinha verdadeira paixão por esse divertimento: ajuntava dinheiro durante o ano para gastar todo com a mascarada. E ninguém o encontrava, domingo ou dia de semana, lavando ou descansando, que não estivesse com a sua calça branca e engomada, a sua camisa limpa, um lenço ao pescoço, e, amarrado à cinta,

${ }^{24}$ De resto, já Óscar Lopes chamara a atenção para as "oscilações e incoerências" nos romances de Abel Botelho e, em particular, n' O Barão de Lavos, bem como para a presença de certos laivos decadentistas que perpassam seu naturalismo (LOPES, 1987, p. 167).

25 TODA IGLESIA, 1995-96, p. 86. 
um avental que lhe caía sobre as pernas como uma saia. Não fumava, não bebia espíritos e trazia sempre as mãos geladas e úmidas. ${ }^{26}$

Nessa caracterização do personagem, está patente uma mudança muito significativa do perfil atribuído ao homoerotismo: este deixa de ser manifestação de uma perversão para se tornar sintoma de uma inversão sexual. O discurso teológico e jurídico cede lugar, definitivamente, ao discurso médico.

Por todos os primas pelos quais ele passa ser analisado - físico, psicológico, social, profissional etc. -, o Albino comporta-se como uma mulher e quase chega a ser reconhecido como tal, pelo menos no pequeno mundo em que vive. Estamos longe da beleza ligeiramente afeminada do efebo da relação pederástica, como vimos nos romances de Adolfo Caminha e Abel Botelho. No caso do lavadeiro d' O Cortiço, o seu caráter feminino não é circunstancial nem temporário, mas sim um dado definitivo e definidor de sua personalidade. Tampouco se trata do resultado de um olhar masculino que, voltando-se para a beleza de um adolescente, o tome como objeto do desejo, passível de receber o mesmo tipo de investimento erótico que uma mulher, como é o caso de Aleixo e Eugênio. O afeminamento de Albino não tem nada a ver com a beleza de um efebo e, mais que o desejo dos homens, é capaz de despertar as reações homofóbicas mencionadas no trecho transcrito.

Em síntese, podemos dizer que, em Bom-Crioulo, O Barão de Lavos e O Cortiço, temos uma galeria de personagens complementares na configuração do homoerotismo como algo abjeto e aviltante, capaz de suscitar não somente desprezo e repugnância, mas ainda reações violentas. No quadro da literatura finissecular em língua portuguesa, podemos dizer que, com a exceção notável de Machado de Assis, esse perfil naturalista do homoerotismo, marcado pelo escândalo, contrastará com a configuração decadentista do mesmo, em que a assimilação social e literária de seu caráter transgressor se dará

${ }^{26}$ AZEVEDO, sd., p. 42. 
por uma via estetizante e a-histórica, conforme veremos a seguir.

\section{Triangulações do desejo}

Anteriormente às obras referidas no item precedente, Fialho d'Almeida já publicara, no volume Contos (1881), "O funâmbulo de mármore", um texto redigido quatro anos antes, muito interessante para o estudo das configurações do homoerotismo, agora em chave decadentista e não mais naturalista.

Trata-se da história improvável de uma contessina florentina rica, livre e excêntrica, obcecada pela beleza masculina de um artista de circo, com quem vivera um tórrido caso de amor, e que, como escultora que era, uma vez morto o amante, logra plasmar suas formas perfeitas numa estátua de mármore. O texto é pródigo na descrição do desejo por essa figura masculina, no contexto de uma relação em que a diferença de classe e de costumes é um atrativo a mais:

Sentia-lhe as mãos grosseiras, calejadas do trapézio, a voz rouca, o hálito alcoolizado, um cheiro a charuto que se metia pelas mucosas dentro. Gostava porém de o agarrar pela cintura, de lhe pender do pescoço nu com todo o peso do corpo, de se entregar com um grande soluço dilacerante, vergada para trás, cabelos soltos e a túnica rasgada de alto a baixo, com a folha dum punhal. (...) O espetáculo de um corpo fortemente criado embriagava-a de uma aspiração criminosa e de uma animalidade fatal: queria-o! ${ }^{27}$

Finda a história, com a morte da contessina ao pé da estátua do funâmbulo, o narrador se permite acrescentar "uma palavra de confidência". Nessa sua intervenção, explica-nos que a contessina não é uma mulher "de verdade", mas uma alegoria do artista em seu afã de perseguir a beleza:

Se quiserem ver passar por instantes a contessina, tal como a sonhamos, vão a um atelier onde se curve um escultor sobre a pedra ou sobre o tronco, ou observem um poeta que febrilmente escreve os alexandrinos do seu poema. Em qualquer dos três, poeta, pintor ou escultor, pousou o beijo da contessina. Não é uma mulher, meus caros, mas o sopro abrasado que 
passa e se extingue, depois de haver criado também o seu funâmbulo de mármore. ${ }^{28}$

Esse conto, de um autor que em vários de seus textos apresenta minuciosas descrições da beleza masculina (corpos atléticos, estatuária clássica etc.), ${ }^{29}$ aponta para um procedimento freqüentemente trilhado em narrativas da época que estamos considerando e que pode ser descrito como um processo de triangulação do desejo. ${ }^{30}$ Uma figura interpõe-se entre sujeito e objeto do desejo, aparentemente desfazendo-lhe o caráter homoerótico, que uma leitura menos superficial pode, no entanto, facilmente recuperar. No caso vertente, não se vê por que o desejo do artista, ao contrário do da própria contessina, haveria de ser exclusivamente estético, sem nenhum componente erótico em relação a seu objeto.

A inverossimilhança da figura da contessina aponta precisamente para a extrema fragilidade da leitura alegórica proposta pela "palavra de confidência" do narrador. Por outro lado, a alegoria sugerida mostra como, nesse contexto decadentista, se desenvolve uma configuração do homoerotismo a partir precisamente dessa figura romântica do artista como ser de exceção, ao qual todas as extravagâncias e excessos são permitidos em nome da arte. ${ }^{31}$

Aceito o caráter homoerótico desse conto, nos termos em que o estamos situando, cabe observar que nele também já está latente um

${ }^{27}$ FIALHO D'ALMEIDA, 1971, p. 210.

${ }^{28}$ FIALHO D'ALMEIDA, 1971, p. 215.

${ }^{29}$ Muito curiosas e sintomáticas as seguintes observações do professor Álvaro Júlio da Costa Pimpão: "Indiferente aos juízos da opinião pública, Fialho exaltará, para si, a beleza masculina, ou melhor, insexuada, mas expressa em fórmulas de máscula anatomia” e, em nota, “(...) a despeito de uma afirmação que me foi feita, recuso-me a ver qualquer paralelo estético entre Fialho e Oscar Wilde ou André Gide" (PIMPÃO, 1945, p. 55).

${ }^{30}$ A obra clássica a esse respeito é de René Girard, Mensonge romantique et vérité romanesque (GIRARD, 1980). 
tema que terá, a seguir, uma longa fortuna literária, a saber, "o homossexualismo como transgressão social, demolição das barreiras entre as classes e, portanto, verdadeira libertação do indivíduo."32

Outro texto, igualmente curioso em seu apagamento do componente homoerótico através desse processo de triangulação, é o conto "O homem das fontes", do volume Serão inquieto (1910), de Antônio Patrício. Respira-se nele a mesma ambiência rara e sofisticada, de luxo e arte, quimera e inverossimilhança, que apontamos no conto anterior, mas ainda bem mais intensa que naquele. O personagemnarrador fala-nos de seus sucessivos encontros com Harry Young, um rapaz rico, enigmático e extravagante, obcecado por desenhar fontes, e que planeja um fantástico "palácio da água". Ao longo da narrativa, aparecem observações profundamente ambíguas sobre o tipo de atração entre os dois rapazes:

Muitas vezes me lembrava dele, eu que também adoro as fontes, com uma simpatia persistente, cúmplice. (...) Se ao menos pudesse conviver com ele e canalizar tão belas qualidades p'ra qualquer coisa de viável, de fecundo! Queria evitar que a sua vida se partisse como uma lufada de vento quebraria aquela arquitetura em pratas d'água, como um sistema arterial de sonho. Mas é esta a primeira noite que falamos e é decerto a última também. E depois, como poderia desviá-lo, por que paixão substituir esta paixão, este culto das fontes religioso?...33

Simultaneamente, toda a longa descrição das fontes, que é o tema que os aproxima, tem inúmeras marcas de sensualidade, num contexto de profunda solidão dos dois personagens. Ao explicar por que gosta das fontes e não do mar, Harry Young - "aquela criatura que uma espécie de loucura poética instalara de vez no meu espírito, (atraindo-me) como p'ra um ser afim, um quase irmão" - conta ao narrador a história de seu pai, homem "ruivo e forte", de "uma beleza viril", cuja vida entra

\footnotetext{
${ }^{31}$ Cf. TODA IGLESIA, 1995-96, p. 87.

${ }^{32}$ FERNANDEZ, 1992, p. 41.
} 
em total decadência física e moral, quando trocou a vida no mar pelo casamento.

Há, pois, no conto de Antônio Patrício um forte componente homoerótico na atração que o narrador sente por Harry Young, o que é ainda reforçado pela história do pai deste último, em que a mulher aparece como perdição de um homem, ao afastá-lo do ambiente exclusivamente masculino da vida de bordo. No entanto, trata-se de um desejo que não chega a superar a mediação totalmente inverossímil do "palácio quimérico da água", projetado pelo personagem para nele habitar com uma evanescente miss Fountain, "se a encontrar um dia". A triangulação do desejo, como se vê, é uma estratégia para dizer e simultaneamente ocultar o homoerotismo, nesse mundo evanescente de sensibilidades raras e situações inverossímeis ou insólitas.

Aplicam-se a esse conto, com perfeição, as seguintes palavras de Hans Mayer:

L'existence du marginal homosexuel dans la société bourgeoise du XIX siècle n'est concevable que comme existence esthétique. (...) Dans tous les cas, il s'agit d'une mimesis esthétique de la réalité. Renoncer au jeu luimême n'est d'aucun profit. Trouver une identité en s'acceptant comme tel ne change rien à la relation de l'homosexuel avec son entourage. ${ }^{34}$

É, portanto, através da mediação estética das fontes, num caminho que parte da contemplação e reprodução gráfica de fontes italianas renascentistas e barrocas para perder-se em projetos delirantes e inverossímeis, que os personagens de Antônio Patrício conseguem configurar suas existências marginais e carentes, dando-lhes um sentido e um lugar, por mais fluido e cambiante que este seja, num mundo decididamente a-histórico.

Nas literaturas de língua portuguesa, o texto que melhor consegue desenvolver essa perspectiva, sempre dentro do contexto decadentista, é A confissão de Lúcio (1914), de Mário de Sá-Carneiro.

33 PATRÍCIO, 1979, p. 61 e 73. 
Trata-se de uma novela em que o narrador-personagem, condenado por um assassinato que ele sustenta não ter cometido, busca reconstituir os fatos supostamente vividos por ele. A história que nos conta é a de um triângulo amoroso, aparentemente banal, que se estabe-lece entre ele próprio, sua amante Marta e o marido desta, Ricardo.

No entanto, uma série de indícios pontilham o texto de ambigüidades várias em relação à circulação do desejo erótico entre os três parceiros. Há todo um clima de alucinação, mistério e incerteza que perpassa o discurso do personagem-narrador, até que, no final, Lúcio presencia Ricardo assassinar Marta e, no mesmo momento, dáse conta de que, na verdade, Ricardo é que fora morto, enquanto Marta desaparecera por completo, sendo ele, Lúcio, o provável criminoso:

...Quando pude raciocinar, juntar duas idéias, em suma: quando despertei deste pesadelo alucinante, infernal, que fora só a realidade, a realidade inverossímil-achei-me preso num calabouço do Governo civil, guardado à vista por uma sentinela... ${ }^{35}$

A confissão de Lúcio sintetiza em linhas vigorosas uma determinada configuração do homoerotismo a que os códigos decadentistas dão forma. Trata-se de uma realidade de tal forma refinada e transgressora - a "realidade inverossímil" por excelência -, que não pode ser, de forma alguma, dita ou percebida na esfera do cotidiano, da linguagem comum e das relações sociais e pessoais prosaicas. Seu espaço não é o da vida social nem seu tempo é o tempo histórico, são antes um tempo e um espaço surreais, nos quais se abre um mundo de alucinações e sonhos, onde a arte confina com o crime, e no qual, só indiretamente, em sofisticadas triangulações e metamorfoses, o desejo homoerótico pode se tornar experiência.

${ }^{34}$ MAYER, 1994, p. 277. 


\section{Eros adolescente}

O Ateneu (1888), de Raul Pompéia, e "Frederico Paciência" (Contos novos, 1947), de Mário de Andrade, trazem um elemento novo ao painel que estamos traçando, ao enfocarem relações homoeróticas entre adolescentes, tendo como pano de fundo o ambiente escolar.

No romance de Pompéia, Sérgio, o protagonista, acaba envolvendo-se a contragosto com um colega do Ateneu, o Sanches, pelo qual sentia profunda repugnância. A relação entre ambos se desenvolve até que a explicitação do desejo sexual por parte do amigo, leva Sérgio a se afastar prudentemente.

O homoerotismo entre adolescentes aparece no romance como algo vil e asqueroso ${ }^{36}$ que, no entanto, é passível de uma certa explicação psicológica e social:

Depois que sacudi fora a tranca dos ideais ingênuos, sentia-me vazio de ânimo; nunca percebi tanto a espiritualidade imponderável da alma: o vácuo habitava-me dentro. Premia-me a força das coisas; senti-me acovardado. Perdeu-se a lição viril de Rebelo: prescindir de protetores. Eu desejei um protetor, alguém que me valesse, naquele meio hostil e desconhecido, e um valimento direto mais forte do que palavras.

Se não houvesse olvidado as práticas, como a assistência pessoal do Rebelo, eu notaria talvez que pouco a pouco me ia invadindo, como ele observara, a efeminação mórbida das escolas. Mas a teoria é frágil e adormece como as larvas friorentas, quando a estação obriga. A letargia moral pesava-me no declive. $\mathrm{E}$, como se a alma das crianças, à maneira do físico, esperasse realmente pelos dias para caracterizar em definitivo a conformação sexual do indivíduo, sentia-me possuído de certa necessidade preguiçosa de amparo, volúpia de fraqueza em rigor imprópria do caráter masculino. ${ }^{37}$

35 SÁ-CARNEIRO, 1982, p. 158. 
Observe-se como, no trecho transcrito, articulam-se os elementos físicos, psicológicos e sociais, como uma possível "explicação" para um comportamento que se supõe aprioristicamen-te como desviante. $\mathrm{Na}$ ótica do texto, haveria um "caráter masculino" paradigmático, que estaria ao final de um processo de evolução psicossomática, como objetivo a ser atingido. No percurso a ser seguido, porém, vários fatores podem ameaçar o desenvolvimento "normal" do rapaz e introduzir aberrantes desvios de conduta.

Dois aspectos, pelo menos, são particularmente relevantes na configuração que o homoerotismo apresenta em O Ateneu. Em primeiro lugar, o caráter de "proteção" que a relação entre rapazes assume, no ambiente hostil da escola. Através dela, é toda a estrutura social, com suas hierarquias de classe, etnia e gênero, que plasma a relação homoerótica, como mímese degradada das relações masculinofeminino patrão-empregado, branco-negro, numa sociedade de classes. O homoerotismo torna-se assim uma atualização tópica e, ao mesmo tempo, uma caricatura grotesca das relações sociais de poder. Em segundo lugar, cabe sublinhar o quanto a "explicação" do homoerotismo como resultante de um bloqueio de um processo evolutivo "normal", como vemos no romance, vai ao encontro de muitas das teorias psicológicas que então se forjavam e que haveriam de ter longa fortuna pelo séc. XX afora.

$\mathrm{Na}$ perspectiva de análise que estamos desenvolvendo, "Frederico Paciência", de Mário de Andrade, poderia ser considerado a antítese de $O$ Ateneu. Toda a lembrança da escola e da relação entre

36 "Só a voz, o simples som covarde da voz, rastejante, colante, como se fosse cada sílaba uma lesma, horripilou-me, feito o contato de um suplício imundo. Fingi não ter ouvido; mas houve intimamente a explosão de todo o meu asco por semelhante indivíduo e muito calmo, desviando apenas a vista, pretextei a falta de um lenço, que me endefluxara a friagem e... fui buscá-lo." (POMPÉIA, 1979, p. 41)

37 POMPÉIA, 1979, p. 34. 
Juca, o personagem-narrador, e seu amigo Frederico é francamente positiva, banhada por uma luz meridiana e impregnada de um hábito de pureza:

Frederico Paciência era aquela solaridade escandalosa. Trazia nos olhos grandes bem pretos, na boca larga, na musculatura quadrada da peitaria, em principal nas mãos enormes, uma franqueza, uma saúde, uma ausência rija de segundas intenções.

Admirava lealmente a perfeição moral e física de Frederico Paciência e com muita sinceridade o invejei. Ora, em mim sucede que a inveja não consegue se resolver em ódio, nem mesmo em animosidade: produz mas uma competência divertida, esportiva, que me leva à imitação. Tive ânsias de imitar Frederico Paciência. Quis ser ele, ser dele, me confundir naquele esplendor, e ficamos amigos. ${ }^{38}$

Mais importante ainda é o fato de, nesse conto, o homoerotismo ser configurado claramente como uma relação entre bomens, em que a masculinidade - e não o afeminamento - é a base sobre a qual se constrói o companheirismo que se estabelece entre os dois parceiros:

Frederico Paciência estava maravilhoso, sujo do futebol, suado, corado, derramando vida. Me olhou com uma ternura sorridente. Talvez houvesse, havia um pouco de piedade. Me estendeu a mão a mal pude corresponder, e aquela despedida de costume, sem palavra, me derrotou por completo. Eu estava envergonhadíssimo, me afastei logo, humilhado, andando rápido pra casa, me esconder. Porém, Frederico Paciência estava me acompanhando!

Diante de uma amizade assim tão agressiva, não faltavam bocas de serpentes. Frederico Paciência, quando a indireta do gracejo foi tão clara que era impossível não perceber o que pensavam de nós, abriu os maiores olhos que lhe vi. Veio uma palidez de crime e ele cegou. Agarrou o ofensor pelo gasnete e o dobrou nas mãos inflexíveis. Eu impassível, assustado. Foi um custo livrar o canalha. Forcejavam pra soltar o rapaz daquelas mãos endurecidas numa fatalidade estertorante. Eu estava com medo, de assombro. Falavam com Frederico Paciência, o sacudiam, davam nele, mas

${ }^{38}$ ANDRADE, 1996, p. 76. 
ele quem disse acordar!"

Eu vingara Frederico Paciência! Com a maior calma, peguei na minha mala que um colega segurava, nem disse adeus a ninguém. Fui embora compassado. Tinha também agora um sol comigo. Mas um sol ótimo, diferente daquele que me separa de meu amigo no caso do livro. Não era glória nem vanglória, nem volúpia de ter vencido, nada. Era um equilíbrio raro - esse raríssimo de quando a gente age como homem-feito, quando se é rapaz. Puro. E impuro. ${ }^{39}$

No entanto, a desaprovação social do homoerotismo não permite que a relação entre Juca e Frederico se aprofunde para além da amizade. Os próprios personagens começam a policiar qualquer forma física de expansão do amor que os unia:

Agora falávamos insistentemente de nossa "amizade eterna", projetos de nos vermos diariamente a vida inteira, juramentos de um fechar os olhos do que morresse primeiro. Comentando às claras o nosso amor de amigo, como que procurávamos nos provar que daí não podia nos vir nenhum mal, e principalmente nenhuma realização condenada pelo mundo. Condenação que aprovávamos com assanhamento. Era um jogo de cabeças unidas quando sentávamos pra estudar juntos, de mãos unidas sempre, e alguma vez mais rara, corpos enlaçados nos passeios noturnos. E foi aquele beijo que lhe dei no nariz depois, depois não, de repente no meio duma discussão rancorosa sobre se Bonaparte era gênio, eu jurando que não, ele que sim. - Besta! - Besta é você! Dei o beijo, nem sei! parecíamos estar afastados léguas um do outro nos odiando. Frederico Paciência recuou, derrubando a cadeira. O barulho facilitou nosso fragor interno, ele avançou, me abraçou com ansiedade, me beijou com amargura, me beijou na cara em cheio dolorosamente. Mas logo nos assustou a sensação de condenados que explodiu, nos separamos conscientes. Nos olhamos no olho e saiu o riso que nos acalmou. Estávamos nos amando de amigo outra vez; estávamos nos desejando, exaltantes no ardor, mas decididos, fortíssimos, sadios. ${ }^{40}$

E é essa lembrança, de um amor que poderia ter sido mas não

${ }^{39}$ ANDRADE, 1996, p. 77 e 81. 
foi, que impregna o discurso do narrador de uma melancolia suave e serena, na evocação da figura de Frederico Paciência. Ainda era a hora do mais tarde...

\section{Homoerotismo e espiritualidade}

No final da década de 50 , a literatura brasileira produz dois grandes romances, extremamente complexos, nos quais o homoerotismo se faz presente com matizes acentuadamente distintos dos até aqui considerados. Referimo-nos a Grande Sertão: Veredas (1956; texto definitivo: 1958), de Guimarães Rosa, e Crônica da casa assassinada (1959), de Lúcio Cardoso. Em ambos, a experiência homoerótica apresenta-se inequivocamente como uma forma de espiritualidade. ${ }^{41}$

Na Crônica, o personagem Timóteo vive recluso em seu quarto, na Chácara dos Meneses, vestido com roupas femininas, acreditando estar possuído pelo espírito de Maria Sinhá, uma antepassada de hábitos viris e transgressores. Sua presença, sua própria existência, é um constante aguilhão a espicaçar o orgulho e a hipocrisia daquela casa habitada pela morte, em lento mas inexorável ritmo de decomposição, do qual o câncer que corrói Nina, personagem que é o centro de todos os ódios e amores dos outros personagens, é não apenas uma vigorosa metonímia, mas o anúncio como que palpável do fim de uma classe social, a oligarquia escravagista, e de seu respectivo universo de sentidos e valores.

O comportamento de Timóteo tem um caráter transgressor, que vai muito além do âmbito da mera satisfação pessoal, projetando-se conscientemente como denúncia e anúncio:

O Sr. Timóteo levantou-se e, com este movimento, o vestido desenlaçou-

${ }^{40}$ ANDRADE, 1996, p. 82. 
se em majestosas pregas.

- Houve tempo - disse ele quase de costas para mim - houve tempo em que achei que devia seguir o caminho de todo o mundo. Era criminoso, era insensato seguir uma lei própria. A lei era um domínio comum a que não podíamos nos subtrair. Apertava-me em gravatas, exercitava-me em conversas banais, imaginava-me igual aos outros. Até o dia em que senti que não me era possível continuar: por que seguir leis comuns se eu não era comum, por que fingir-me igual aos outros, se era totalmente diferente? Ah, Betty, não veja em mim, nas minhas roupas, senão uma alegoria: quero erguer para os outros uma imagem da coragem que não tive. Passeio-me tal como quero, ataviado e livre, mas ai de mim, é dentro de uma jaula que o faço. É esta a única liberdade que possuímos integral: a de sermos monstros para nós mesmos.

Silenciou, dominado pela emoção. Depois, mais baixo, como se o dissesse apenas para si próprio:

- Foi a isto que eles reduziram o meu gesto, Betty. Transfor-maramno na mania de um prisioneiro, e estas roupas, que deveriam constituir o meu triunfo, apenas adornam o sonho de um homem condenado. Mas um dia, está ouvindo? - um dia eu me libertarei do medo que me retém, e

${ }^{41}$ Com Hans Urs von Balthasar, estamos entendendo espiritualidade "como la actitud práctica o existencial fundamental de una persona, consecuencia y expresión de su manera de entender la vida religiosa o, más generalmente, la vida éticamente comprometida. Es la tónica, por así decirlo, de su actividad y estado habitual en virtud de sus concepciones y opciones últimas" (BALTHASAR, 1985, p. 283). Nessa perspectiva, a espiritualidade se caracteriza como abertura à totalidade do ser enquanto totalidade absoluta, na medida mesma em que "a exigência e pretensão do espírito à verdade implica a absoluto" (Idem, ibidem., p. 284). Como movimento de unificação do múltiplo e do disperso sob o signo do absoluto, a espiritualidade é simultaneamente eros, anamnese e antecipação. Sei impulso fundamental é "fazer-se totalidade de fundo e conteúdo em todo o relativo" (Idem, ibidem., p. 285), convertendo a referência ao absoluto numa decisão que desencadeie a ação objetiva. Para além do eros, como anseio pelo absoluto, e da ação, como adequação à realidade, a espiritualidade tem ainda uma terceira dimensão, de entrega, em que se deixa atuar e possuir pela verdade absoluta. 
mostrarei a eles, ao mundo, quem na verdade eu sou. Isto acontecerá no instante exato em que o último dos Meneses deixar pender o braço num gesto de covardia. Só aí terei forças para gritar: "Estão vendo? Tudo o que desprezam em mim, é sangue dos Meneses!"²

Na seqüência de seu diálogo com a criada Betty, Timóteo explicita ainda mais o sentido espiritual de sua postura, numa linguagem que ecoa textos fundadores do cristianismo, muito particularmente o Evangelho de São João:

- São coisas muito altas para mim. Senhor Timóteo. Em todo caso, se para o senhor a felicidade consiste nisto...

Com um movimento quase de violência voltou-se para mim, enquanto uma sombra descia à sua face:

- Não, Betty, não é de felicidade que se trata. Não afrontaria ninguém se fosse apenas por causa da felicidade. Mas é da verdade que se trata - e a verdade é essencial a este mundo. ${ }^{43}$

Mais que nenhum outro personagem das literaturas de língua portuguesa, Timóteo encarna o homoerotismo como transgressão, isto é, inversão e deslocamento de valores e sentidos. Concebida como forma de espiritualidade e, portanto, alçada à condição de verdade absoluta do personagem, a experiência homoerótica unifica todo um mundo disperso, convertendo-se simultaneamente em eros universal, anamnese e antecipação profética do novo. No entanto, o sistema de poder social e cultural defende-se continuamente, ao tentar enquadrar a transgressão num esquema qualquer, discipli-nando-a e privando-a de seu impacto contestador. Como escreve Hans Mayer,

Mais au cours du même processus social, de la Renaissance à la fin de l'Ancien Régime, où l'on s'efforçait de passer sous silence, sinon de soumettre à la répression, tout transgresseur existentiel reconu comme tel, une évolution se dessina qui domestiqua par la notion de "compréhension" les marginaux volontaires, les transgresseurs du savoir et du sentiment,

${ }^{42}$ CARDOSO, 1996, p. 56. 
rabaissant du même coup leur particularité au rang de manie, de spleen, de maladie nerveuse. ${ }^{44}$

Eis por que, em meados dos anos 70, um autor revolucionário como Mario Mieli colocava a questão política do homoerotismo nos seguintes termos:

La lotta omosessuale rivoluzionaria non ha come obiettivo il conseguimento della tolleranza sociale per i gay, bensí la liberazione del desiderio omoerotico in ogni essere umano: finché vi saranno persone "normali" che "accettano" gli omosessuali, la specie non avrà riconosciuto il proprio desiderio omosessuale profondo, non si sarà resa conto della sua universale presenza e soffrirà senza rimedio delle conseguenze di questa rimozione che è repressione. Noi omosessuali rivoluzionari, oggi, seduciamo gli altri a imitarci, a venire con noi, affinché tutti insieme si giunga al sorvertimento della Norma che reprime l'(omo)erotismo. ${ }^{45}$

É precisamente contra esse tipo de enquadramento e domesticação do homoerotismo, denunciado por Hans Mayer e Mario Mieli, que Timóteo luta. Na cena em que vai ao velório de Nina, carregado numa rede por três negros - autêntica paródia da sociedade escravocrata -, finalmente ele consegue o seu "triunfo", conforme reconhece o irmão Valdo:

Acho, e afirmo isto sem nenhuma hesitação, que tudo ainda estaria salvo se Timóteo não houvesse descido da rede. Sua entrada poderia ser extraordinária, mas poderia muito bem significar apenas a entrada de um homem doente. Descendo, vestido naqueles trajes mais do que impróprios, cometia um insulto, e um insulto que atingia todo o mundo reunido naquela sala. Os homens suportam uma certa dose de grotesco, mas até o momento em que não se sentem implicados nele. De pé, parado diante daquela gente, Timóteo era como a própria caricatura do mundo que representavam - um ser de comédia, mas terrível e sereno. Vestiase com qualquer coisa que não se poderia chamar de vestido, mas que fora um vestido - quando, em que época, em que bailes - e que agora, cor

42 CARDOSO, 1996, p. 58.

${ }^{44}$ MAYER, 1996, p. 23. 
desbotada de malva, esgarçava-se em remendos colados às pressas, e de fazendas de tons e panos diferentes. Trazia os braços e o pescoço juncados de pulseiras e de colares - pulseiras e colares que eu não sabia de onde havia desenterrado, mas que evidentemente eram jóias de família, conservadas em arcas e baús, entre linhos e sedas estrangeiras, miradas e remiradas pelos parentes cobiçosos, e que agora resplandeciam, puras, sobre aquele corpo que tantos julgavam marcado pela ignomínia. Lento, ele percorreu com o olhar a multidão fascinada que o fitava: ninguém ousava fazer um só gesto, nem pronunciar a mínima palavra. ${ }^{46}$

Esse triunfo, porém, tem um preço e este é muito alto: a total entrega do personagem à sua verdade, num processo que atinge as proporções de um autêntico martírio, isto é, de um impávido testemunho. Na Crônica, o homoerotismo não é um caminho fácil, mas sim uma espiritualidade dilacerante, feita de exílio, renúncia e indi-gência. Daí a sua força extraordinária de interpelação e de denúncia.

Pois bem, foi num desses momentos, precisamente, que eu o vi - minha mão tremeu, e abaixei a cortina precipitadamente. Havia-o visto - e era o único ser vivo entre as flores. Nina, era um homem, louro, moço, embriagado de si mesmo e da existência como um frágil deus pagão. Reconhece-o agora, consegue situá-lo nesta lonjura em que se encontra, pode revê-lo, Nina, tal como depois tivemos tantas vezes de reinventá-lo para a nossa sede, a nossa impaciência e a nossa saudade? Era um homem, e a mão temerosa que abaixou a cortina voltou a suspendêla, trêmula, emocionada de todas as surpresas deste mundo. Era um homem, e eu que julgava tê-lo visto tão próximo à minha janela, descobri que olhava não para mim, mas para a imagem que via na janela junto à minha - e esta janela era a sua, Nina. Guardei o segredo, e se agora o devolvo, é num puro gesto de gratidão: foi essa descoberta, e a visão diária desse homem, a única coisa que me alimentou durante este longo exílio no me quarto - meu único contato com o mundo, o único enredo, solitário e triste, de que participei desde que voluntaria-mente aceitei morrer para

45 MIELI, 1977, p. 63.

${ }^{46}$ CARDOSO, 1996, p. 542. 
a piedade dos outros. Quantas vezes, ao desaparecer ele, e ao tombar de novo a cortina sobre minhas trevas, eu sentia que havia ficado em minhas mãos, e durante muito tempo ainda brilhava em minhas retinas, um pouco do louro que compunha o sol do amanhecer. ${ }^{47}$

Esse amor mudo de Timóteo por André aproxima-o da outra grande outsider do romance, Nina, a mulher que veio do Rio e mãe supostamente incestuosa. As atitudes transgressoras de ambos colocamnos paradoxalmente no centro do universo decadente dos Meneses, cuja hipocrisia e vacuidade desmascaram violentamente. Simultaneamente, Timóteo e Nina são também sinais anunciadores de um mundo novo, livre de hierarquias e preconceitos.

Se na Crônica, o homoerotismo aparece com esse perfil de denúncia profética e testemunho antecipador de uma nova realidade prestes a se manifestar no processo de superação da figura caduca deste mundo - em perspectiva escatológica, portanto -, em Grande Sertão, ele adquire a configuração de um longo processo ascético que conduz ao conhecimento de si e do mundo e a uma união (de natureza mística, pode-se dizer) que só é possível na perda irremediável do próprio objeto de amor buscado com afinco.

No quadro iniciático de Grande Sertão, a paixão impossível por Diadorim é um caminho que Riobaldo vai ter que aprender a trilhar, como passagem obrigatória para um "destino melhor":

De Diadorim não me apartava. Cobiçasse de comer e beber os sobejos dele, queria pôr a mão onde ele tinha pegado. Pois, por que? Eu estava calado, eu estava quieto. Eu estremcia sem tremer. Porque eu desconfiava mesmo de mim, não queria existir em tenção soez. Eu não dizia nada, não tinha coragem. O que tinha era uma esperança? Mesmo parava tempos no pensar numa mulher achada: Nhorinhá, a minha moça Rosa'uarda, aquela mocinha Miosótis. Mas o mundo falava, e em mim tonto sonho se desmanchando, que se esfiapa com o subir do sol, feito neblina noruega movente no frio de agosto.

A noite que houve, em que eu, deitado, confesso, não dormia; com dura mão sofreei meus ímpetos, minha força esperdiçada; de tudo me

${ }^{47}$ CARDOSO, 1996, p. 550. 
prostrei. Ao que me veio uma ânsia. Agora eu queria lavar meu corpo debaixo da cachoeira branca dum riacho, vestir terno novo, sair de tudo o que eu era, para entrar num destino melhor. ${ }^{48}$

Por outro lado, é somente na perda de Diadorim, que se abrirá para Riobaldo a possibilidade de compreender em profundidade seu próprio destino:

No que eu no meu destino não pensei. Diadorim, em sombra de amor, foi que me perguntou aquilo:

- "Riobaldo, tu achasses que, uma coisa mal principiada, algum dia pode que terá bom fim feliz?"

Ao que eu, abirado, reagi:

- "Mano meu mano, te desconheço?! me chamo não é Urutu-Branco? Isto, que hei-de já, maximé!"

Diadorim persistiu calado, guardou o fino de sua pessoa. Se escondeu; e eu não soubesse. Não sabia que nós dois estávamos desencontrados, por meu castigo. Hoje, eu sei; isto é: padeci. O que era uma estúrdia queixa, e que fosse sobrosso eu pensei. Assim ele acudia por me avisar de tudo, e eu, em quentes me regendo, não dei tino. Homem, sei? A vida é muito discordada. Tem partes. Tem artes. Tem as neblinas de Siruiz. Tem as caras todas do Cão, e as vertentes do viver. ${ }^{49}$

O desejo homoerótico, reconhecido e negado a um tempo, é para Riobaldo a concretização do impasse de viver e a abertura necessária para uma perspectiva transcendente. Como impossibilida-de prática e teórica, diferentemente da Crônica da casa assassinada, o homoerotismo em Grande Sertão não pode ser uma forma unificadora de espiritualidade, mas tão-somente o momento de crise radical de sentidos, valores, e linguagens, num movimento absoluto de entrega, despojamento e abandono. Nesse sentido, se na Crônica temos uma espiritualidade profética e martirial, em Grande Sertão temos uma espiritualidade do êxodo e da transfiguração.

Meio arrependido do dito, puxei outra conversa com Diadorim; e ele me

${ }^{48}$ ROSA, 1980, p. 240. 
contrariou com derresposta, com o pique de muita solércia. Me lembro de tudo. O que me deu raiva. Mas, aos poucos, essa raiva minou num gosto concedido. Deixei em mim. digo ao senhor: se deixei, sem pejo nenhum, era por causa da hora - a menos sobra de tempo, sem possibilidades, a espera de guerra. Ao que, alforriado me achei. Deixei meu corpo querer Diadorim; minha alma? Eu tinha recordação do cheiro dele. Mesmo no escuro, assim, eu tinha aquele fino das feições, que eu não podia divulgar, mas lembrava, referido, na fantasia da idéia. Diadorim - mesmo o bravo guerreiro - ele era para tanto carinho: minha repentina vontade era beijar aquele perfume no pescoço: a lá, aonde se acabava e remansava a dureza do queixo, do rosto... Beleza - o que é? E o senhor me jure! Beleza, o formato do rosto de um: e que para outro pode ser decreto, é, para destino destinar... E eu tinha de gostar tramadamente assim, de Diadorim, e calar qualquer palavra. Ele fosse uma mulher, e à-alta e desprezadora que sendo, eu me encorajava: no dizer paixão e no fazer - pegava, diminuía: ela no meio de meus braços! Mas, dois guerreiros, como é, como iam poder se gostar, mesmo em singela conversação - por detrás de tantos brios e armas? Mais em antes se matar, em luta, um o outro. E tudo impossível. Três-tantos impossível, que eu descuidei, e falei: - ... Meu bem, estivesse dia claro, e eu pudesse espiar a cor de seus olhos... -; o disse, vagável num esquecimento, assim como estivesse pensando somente, modo se diz um verso. Diadorim se pôs pra trás, só assustado. - O senhor não fala sério! - ele rompeu e disse, se desprazendo. "O senhor" - que ele disse. Riu mamente. Arrepio como recaí em mim, furioso com meu patetear. - Não te ofendo, Mano. Sei que tu é corajoso... - eu disfarcei, afetando que tinha sindo brinca de zombarias, recompondo o significado. Aí, e levantei, convidei para se andar. Eu queria airar um tanto. Diadorim me acompanhou. ${ }^{50}$

A esse fugaz movimento de epifania da verdade, da suaverdade, Riobaldo reage imediatamente "recompondo o signifi-cado": o homoerotismo dá lugar à homossociabilidade da identidade masculina convencional, que dramatiza e elimina o desejo homoerótico, convertendo-o em motivo de chacota e pilhéria. Nessa conversão, o discurso obscurece a manifestação da verdade, reduzindo-a aos

49 ROSA, 1980, p. 381. 
estreitos limites do razoável e do conhecido.

Quando Riobaldo puder novamente aceitar sem pejo seu amor por Diadorim, perceberá que "aquela era a hora do mais tarde"... O homoerotismo será por isso a sua "neblina", um caminho privilegiado para o conhecimento de si e do mundo, através do dom, através da dor-Diadorim.

\section{Referênicas Bibliográficas}

\section{Obras literárias}

ANDRADE, Mário de. Contos novos. 16. ed. Belo Horizonte/Rio de Janeiro: Vila Rica, 1996.

AZEVEDO, Aluísio. O Cortiço. Rio de Janeiro: Ediouro, s.d.

BOTELHO, Abel. O Barão de Lavos. Porto: Lello, 1982.

CAMINHA, Adolfo. Bom-Crioulo. São Paulo: Ática, 1983.

CARDOSO, Lúcio. Crônica da casa assassinada. 2. ed. Madri/Paris/

México/Buenos Aires/São Paulo/Rio de Janeiro: ALLCA XX, 1996.

FIALHO D'ALMEIDA. Contos. Lisboa: Clássica, 1971.

MACHADO DE ASSIS. Reliquias de Casa Velha. Rio de Janeiro/São Paulo/Porto Alegre: W.M. Jackson, 1952, 1ํ vol.

PATRÍCIO, Antônio. Serão inquieto. Lisboa: Assírio e Alvim, 1979. POMPÉIA, Raul. O Ateneu: crônica de saudades. 6. ed. São Paulo: Ática, 1979.

ROSA, Guimarães. Grande Sertão: Veredas. 14 ed. Rio de Janeiro: José

${ }^{50}$ ROSA, 1980, p. 436. 
Olympio, 1980.

SÁ-CARNEIRO, Mário de. A confissão de Lúcio. 6. ed. Lisboa: Ática, 1982.

\section{Obras de teoria e crítica}

ALLEN, Dennis. Homosexualité et littérature. Franco-Italica, serie contemporanea, Alessandria, n. 6, p. 11-27.

ANTELO, Raul. Protocolos de leitura: o gênero em reclusão. Gragoatá, Niterói, n. 3, p. 9-22, 2º sem. 1997.

BALTHASAR, Hans Urs von. Puntos centrales de la fe. Madri: BAC, 1985. BOSWELL, John. "Hacia un enfoque amplio. Revoluciones, universales y categorías relativas a la sexualidad" in STEINER, George e BOYERS, Robert(org.). Homosexualidad: literatura y politica. Madri: Alianza, 1985.

CHAUNCEY Jr., George. "Christian Brotherhood or Sexual Perversion? Homosexual Identities and the Construction of Sexual Boundaries in the World War I Era" in DUBERMAN, Martin et alii (eds.). Hidden from History: Reclaiming the Gay and Lesbian Past. Nova York: Meridian, 1990, p. 294-317.

COSTA, Jurandir Freire. A inocência e o vício: estudos sobre o homnoerotismo. 3 ed. Rio de Janeiro: Relume Dumará, 1992.

CRUZ, Décio Torres. Lovers in arms: literary portrayal of male love in the military. Gragoatá, Niterói, n. 3, p. 47-67, 2º sem. 1997.

DOLLIMORE, Jonathan. Sexual Dissidence: Augustine to Wilde, Freud to Foucault. Oxford: Clarendon Press, 1996.

FERNANDEZ, Dominique. Il ratto di Ganimede: la presenza omosessuale nell'arte e nella società. Milão: Bompiani, 1992.

GIRARD, René. Mensonge romantique et vérité romanesque. Paris: Grasset, 1980.

LOPES, Óscar. Entre Fialho e Nemésio: estudos de literatura portuguesa contemporânea. Lisboa: INCM, 1987, vol. I.

MAGGI, Armando. La rivoluzione culturale. Babilonia, Milão, n. 164, 
p. 14-16, marzo 1998.

MARTEL, Frédéric. Le rose et le noir. les homosexuels en France depuis 1968. Paris: Seuil, 1996.

MAYER, Hans. Les marginaux: femmes, juifs et homosexuels dans la littérature européenne. Paris: Albin Michel, 1996.

MIELI, Mario. Elementi di critica omosessuale. Turim: Einaudi, 1977.

PEREIRA, Astrojildo. Machado de Assis: ensaios e apontamentos avulsos. Rio de Janeiro: Livraria São José, 1959.

PIETRANTONI, Luca. Cultura gay... che? Babilonia, Milão, n. 164, p. 12-13, marzo 1998.

PIMPÃO, Álvaro Júlio da Costa. Fialho: introdução ao estudo da sua estética. Coimbra: Coimbra, 1945, vol. I.

ROBINSON, Christopher. Scandal in the Ink: Male and Female Homosexuality in Twentieth-century French Literature. Londres/ Nova York: Cassell, 1995.

SASLOW, James M. Ganimedes en el Renacimiento: la homosexualidad en el arte y en la sociedad. Madri: Nerea, 1989.

TODA IGLESIA, María Ángeles. "That horrible, horrible fate of mine!": el héroe homosexual en el decadentismo. Stylistica, Sevilha, n. 4, p. 85-91, 1995-1996.

WEEKS, Jeffrey. "Inverts, Pervents, and Mary-Annes: Male Prostitution and the Regulation of Homosexuality in England in the Nineteenth and Early Twentieth Century" in DUBERMAN, Martin et alii (eds.). Hidden from History: Reclaiming the Gay and Lesbian Past. Nova York: Meridian, 1990, p. 195-211.

\section{Resumo}

O objetivo deste texto é investigar as diferentes configurações que o homoerotismo masculino assumiu nas literaturas brasileira e portuguesa no período anterior à Revolução Sexual dos $\operatorname{anos} 60$. 


\section{Abstract}

This paper intends to investigate the various configurations taken by male homoeroticism in Brazilian and Portuguese literatures prior to the Sexual Revolution of the 60's. 